\title{
Genetic and pharmacogenetic counselling in psychiatric practice
}

\author{
Poradnictwo genetyczne i farmakogenetyczne w psychiatrii
}

Joanna M. Pawlak ${ }^{1}$, Joanna W. Twarowska-Hauser ${ }^{2}$

\section{ABSTRACT}

Genetic research in psychiatry has been developing intensively for over 30 years. The social knowledge on the role of genes in the predisposition to diseases and their importance for treatment effects increases.
Psychiatric genetic counselling is a service provided under healthcare around the world. The aim of this paper is to present psychiatric genetic counselling, its role for patients and its application in the clinical practice at the current state of knowledge. We discuss these aspects of genetic consultation which relate to mental health. Psychiatric genetic counselling is rarely available in the Polish psychiatric care system and access to specialist training is limited. We indicate that the patient's adaptation to the genetic burden can bring potential benefits, e.g. better compliance with doctor's prescriptions. Based on current expert recommendations, we discuss pharmacogenetic tests which are useful in clinical practice. In particular, we analyse the polymorphisms of CYP2D6, CYP2C19 and histocompatibility complex genes HLA.

\section{STRESZCZENIE}

Badania genetyczne w psychiatrii rozwijają się intensywnie od ponad 30 lat. Coraz większa jest świadomość społeczna roli genów w predyspozycji do choroby i ich znaczenia dla efektów leczenia. W systemach opieki zdrowotnej w świecie i Europie wprowadza się poradnictwo genetyczne w psychiatrii. Celem pracy było przedstawienie założeń poradnictwa genetycznego w psychiatrii, jego znaczenia dla pacjentów oraz zastosowania użytecznego dla klinicystów na obecnym etapie wiedzy. Omówiono etapy konsultacji genetycznej z uwzględnieniem specyfiki zaburzeń psychicznych. 
Porady takie są rzadko realizowane w polskim systemie opieki psychiatrycznej, a dostęp do specjalistycznego szkolenia jest ograniczony. Wskazano możliwe do osiągnięcia korzyści dla pacjentów z zaadaptowania się do sytuacji wynikającej z istniejących obciążeń genetycznych, jak na przykład poprawa we współpracy z lekarzem w procesie leczenia. Na podstawie aktualnych stanowisk ekspertów omówiono testy farmakogenetyczne, których zastosowanie może być przydatne w praktyce klinicznej. Wykonuje się głownie badania polimorfizmów genów cytochromów CYP2D6, CYP2C19 oraz układu genów zgodności tkankowej HLA.

\section{Introduction and aim of the paper}

Modern society has easier access to information on the progress of biotechnology and medical science, and a growing awareness of the role of genes in human health and diseases. Family history of mental disorders has been observed for centuries. Epidemiological premises and the development of genetics have paved the way for a modern discipline which discusses the complex and multigenic etiopathogenetic basis of these diseases. The current development of direct-to-consumer genetic services may lead to an increased demand for professional individual interpretation of the results by a physician (Austin, 2013). Failure to provide a patient with adequate interpretation of the test results which are likely to evoke high anxiety is inappropriate in terms of medical ethics.

Genetic research in psychiatry has developed in the last decades of the 20th century. Initially, it drew on the tools and experiences of clinical genetics of monogenic diseases (Austin, 2013). Technological advancement and determination of multigenetic conditions with GWAS and PRS methods have produced strong scientific evidence that most mental disorders belong to more complex diseases in terms of the mechanism of development (Cardno and Owen, 2014).

In Poland, research centres in Poznań, Szczecin, Wrocław, Warszawa and other academic cities conducted genetic research in psychiatry. Furthermore, informal consultations were provided for interested patients. In 1999, the Department of Psychiatry of the Medical Academy in Poznań opened the Laboratory and the Department of Genetics in Psychiatry under the supervision of prof. dr hab. Joanna Twarowska-Hauser. In autumn 2019, the Laboratory of Psychiatric Genetic Counselling was established as a separate unit. These efforts were inspired by own experience, Adapt Clinic in Vancouver, Canada, operating since 2012, and the research network developed under the EnGagE (Enhancing Psychiatric Genetic Counselling, Testing, and Training in Europe).

This paper presents the principles of psychiatric genetic counselling, its role for patients and its application in the clinical practice at the current state of knowledge.

\section{Literature review}

\section{How to define psychiatric genetic counselling?}

Today, genetic counselling is defined as a process that helps people understand the medical, psychological and family implications of the genetic burden and adapt to them (Resta et al., 2006). Harper emphasises the importance of communicating the consequences of the disease, the way it is inherited and the methods that can help to stop, avoid or minimise the symptoms (as cited in Hauser, 2011). In addition, the humanistic and holistic aspects should be taken into account to identify the psychosocial needs of patients and respect their rights, including the right to autonomy and informed decisions. Historically, genetic knowledge of mental disorders was used for specific purposes (Propping, 2005). Bearing that in mind, high ethical standards and competence in providing advice and referring to genetic testing in this field shall be required.

In some countries, such as the United States, Canada, France, Norway, Portugal, Spain, Romania and Great Britain, the profession of genetic counsellor has been introduced. This is also the case in Australia, South Africa, Israel and the Philippines. In these countries, training courses which prepare for this profession are offered (Moldovan et al., 2019). In Poland, genetic counselling is provided by doctors who specialise in clinical genetics. The number of molecular tests which are financed by the National Health Fund is limited. By contrast, the offer of commercial laboratories which perform tests "on request" and at the client's expense is wide and available worldwide, including to Polish stakeholders.

Clinical genetics specialists know that we do not currently have molecular tests to diagnose or predict mental disorders (Austin, 2013). This discourages dialogue with patients who want to know family burden of mental disorders. As a result, genetic consultation is significantly reduced in this group (Appelbaum and Benston, 2017; Lyus, 2007; Monaco et al., 2010). Moreover, psychiatrists often do not feel confident enough in interpreting the results of molecular tests. There are no postgraduate training courses in psychiatric genetics in Poland. Specialist training is conducted periodically by the Bournemouth University, Great Britain (https://research.bournemouth. 
ac.uk/wp-content/uploads/2016/10/PG4GC3.pdf, 2020). In 2019, under the CA17130 Enhancing Psychiatric Genetic Counselling, Testing, and Training in Europe, a workshop on this subject was held in Paris (https://www.cost. $\mathrm{eu} /$ cost-action/enhancing-psychiatric-genetic-counselling-testing-and-training-in-europe/\#tabs|Name:overview, 2020). The workshop was attended by Polish doctors and laboratory diagnosticians working in the field of psychiatric genetics.

The researchers of the Poznan Medical University who were trained in this way may provide consultations at the request of a patient or a family with psychiatric burden and no referral is needed, as in the case of visits to a psychiatrist. Referrals to molecular tests, if any, are issued by clinical genetics specialists after a psychiatrist has referred to the clinic for such tests. In some cases, especially in the case of intellectual disabilities and autism, this procedure is justified provided that a specific mutation is suspected. On the other hand, in the case of some mutations related to congenital malformation syndrome (e.g. heart and palate defects), it is highly likely that psychopathological symptoms will manifest. For example, in deletion syndrome 22q11.2 (DiGeorge syndrome), the risk of contracting schizophrenia exceeds the population risk more than twenty times (Bassett et al., 2017; Fung et al., 2010). In this genetic syndrome, the risk of generalised anxiety syndrome is also higher (Fung et al., 2010). However, the majority of patients with 22q11.2 deletion do not suffer from schizophrenia. Among patients with a diagnosed schizophrenia, 22q11.2 deletion is found in 0.5-1\% of them (Bassett et al., 2010).

In such situations, molecular diagnosis can be carried out in the prenatal and early childhood period. However, it should be emphasised that the diagnosed mutation cannot be used to diagnose schizophrenia and stigmatise the patient. Searches for CNV (copy number variants) mutations in mental disorders provide further evidence for their multigenic nature (Bassett et al., 2017).

Assuming that we reveal a strong genetic predisposition to schizophrenia, i.e. a disease which is likely to develop some time after the molecular test, the potential for the use of specific prophylactic measures should be taken into consideration. In the cases where the risk of psychosis is high, pharmacological and psychotherapeutic strategies have been developed to reduce the rate of transition to a full-blown disease (Fusar-Poli et al., 2016; Schmidt et al., 2015). However, there is currently no evidence that any of these strategies works particularly well in improving clinical outcomes (Nelson et al., 2020). Serious ethical concerns arise about performing genetic testing, especially in children, for diseases which have no preventive treatment, for example Huntington's disease.

Genetic consultation in psychiatry covers three essential aspects: interpretation of family medical burden, education and support to help the patient make informed decisions (Resta et al., 2006). It is often difficult to prepare a genealogical tree with mental disorders due to the lack of medical records or unrevealed psychiatric diagnoses in families. Next, the risk of the disorders is estimated on the basis of empirical research (Hill and Sahhar, 2006) and family burden. In many cases, there are high expectations about how precise such predictions are and this is because environmental factors are ignored. In the case of mental disorders, it is not possible to precisely determine the individual risk of the disease (Hauser, 2011, p. 20).

The second aspect, i.e. education, involves providing information on heritability, molecular testing, prevention of mental disorders and the distinction between research and diagnostic results. This step is necessary as it is intended to free the patient from unjustified pessimism and determinism related to genetic outcomes or from equally unjustified optimism about medical capabilities (Friesen et al., 2016; Moldovan et al., 2019). Note that it is the patient who is supposed to assess the significance of the information provided. Some people are likely to see the $50 \%$ risk of the disease as a huge burden while others as the $50 \%$ chance of being healthy.

In such cases, the doctor's ability to empathise with a patient is essential. It is necessary to help the patient adapt to the genetic burden and tolerate it by reducing anxiety, feeling of helplessness and lack of control. With the acquired knowledge and balanced emotions, patients can make conscious choices considering their strengths and weaknesses. In this respect, psychiatric genetic counselling is close to selected concepts of psychotherapy and may prove to be difficult for a genetic specialist or biotechnologist. Therefore, it is justified to arrange at least two meetings for psychiatric genetic counselling to provide support in the adaptation process and facilitate the engagement of an interdisciplinary team.

The commercial availability of the so-called diagnostic genetic tests for mental disorders should be critically assessed for a number of reasons. Firstly, making a psychiatric diagnosis based on the very result of a test for the presence or absence of selected genetic polymorphisms is a wrong approach. The list of polymorphisms which affect the disease is currently not complete. According to the criteria assumed in ICD-10 and DSM-5 international classifications, only clinical symptoms can serve as a basis for diagnosis. Sending the material for molecular testing (often abroad) or the test result (often by electronic means with unspecified securities) generates multiple risks (inappropriate storage conditions, inability to verify the source of the sample, lack of control over data confidentiality, access to genetic data for commercial entities which operate outside the Polish legal system and others). If the test result is communicated to patients but no reliable interpretation is provided to them, this may lead to trauma and affect their life decisions.

Tsuang et al. indicate six stages of genetic consultation in psychiatry (Tsuang et al., 2001), consistent with the above mentioned aspects: 
- Determine a diagnosis (make a diagnosis or verify it, depending on the stage at which the consultation takes place);

- Prepare the genealogical tree with the necessary medical data;

- Assess the inheritance model and the risk of the disease (taking into account partial overlap of polymorphisms predisposing to different disorders and phenotypic diversity);

- Assess the patient in emotional and intellectual terms and adapt the message to their needs;

- Identify the strengths and weaknesses based on the information provided and help the patient accept them in accordance with their values, expectations and plans;

- Assist in the determination of further proceedings, including decision on molecular tests and clinical recommendations;

- Prepare a summary, with additional data, if any, after further observation, and draw up a written post-consultation findings.

\section{Benefits for patients. The demand for counselling and its effects}

Patients who report the need for genetic consultation mostly belong to the following groups:

- People with a diagnosis of a mental disorder who plan to have offspring or are expecting a child;

- Parents or grandparents of children with a higher risk of mental disorders;

- Parents of children with a diagnosis of mental disorders;

- Hitherto healthy siblings or children of people with a diagnosis of a mental disorder;

- Other relatives with a family burden regarding a mental disorders;

- People with a diagnosis of a mental disorder who seek more information on their health;

- People with alarming symptoms not yet classified who look for an explanation for their symptoms (Peay and Austin, 2011).

The motivation and expectations of the patients may vary, but the general pattern for advice, as described above, is the same. People who seek advice experience anxiety about themselves and their loved ones, and feelings of guilt or helplessness.

Studies in the countries in which psychiatric genetic counselling has been included in the offer of medical services have shown its beneficial effects. Genetic consultation is intended to provide the patient with knowledge of risk, nearly as detailed as medical data, and to ensure that the patient will not rely on unverified sources. The patient will obtain information about modifiable risk factors and protective factors (risk reduction). The reliability of the diagnosis and accuracy of the procedure will be increased. Expectations about genetic tests and gene therapy will be more realistic than before (Peay and Austin, 2011).

In the period from February 2012 to January 2013, a group of researchers from Adapt Clinic (Vancouver) collected data on empowerment and self-efficacy in the disease using a specially designed GCOS (Genetic Counseling Outcome Scale) and IMSES (Illness Management Self Efficacy Scale), (Inglis et al., 2015). The authors define the empowerment as a set of beliefs of people from families with genetic burden that they have some control over the situation and hope for the future. IMSES was filled only by patients with a diagnosed mental disorders in their history. GCOS included also healthy people with a family burden. Both scales showed a statistically significant increase in parameters after genetic consultation in psychiatry. This results from a reduced sense of stigma, hopelessness and helplessness, an improved quality of life and the use of support.

Patients also improved their knowledge of the disease aetiology and reduced blaming themselves for the disease. Better understanding of the disease aetiology may improve cooperation in pharmacological treatment (Costain et al., 2014b). In members of the families, the fear of recurrence was reduced (Costain et al., 2014a).

\section{Usefulness of pharmacogenetics in psychiatrist's practice}

The aim of pharmacogenetic studies is to determine genetic markers for the clinical effect of drugs and the likelihood of side effects. The studies include analyses of single polymorphisms of candidate genes related to the pharmacokinetic and pharmacodynamic mechanism of action of drugs and genome-wide association studies (GWAS) (Foley et al., 2017; Rybakowski, 2019; Rybakowski, 2014; Serretti, 2017; van Westrhenen et al., 2020; Yoshida and Müller, 2019).

The International Society of Psychiatric Genetics (ISPG) has provided recommendations on the use of pharmacogenetic tests in clinical practice since 2013. The ISPG recommendation which is currently in use was adopted in November 2019. According to the experts of the International Society of Psychiatric Genetics, the existing results of pharmacogenetic tests are scientifically significant. A number of genetic markers showing the therapeutic effect of drugs used in psychiatry were identified. Most of the markers currently do not meet the criteria in a clinical trial and thus further research is needed to confirm their importance in clinical practice (Hirschtritt et al., 2016; Nurnberger et al., 2018).

ISPG experts indicate that CYP2D6 and CYP2C19 gene variants, related to the metabolism of drugs used in psychiatry, especially antidepressants and antipsychotics, may be important in clinical practice. CYP2D6 and CYP2C19 gene variants affect the metabolism of drugs 
and thus generate the risk of adverse reactions or lack of therapeutic efficacy of drugs. A genetic test may be helpful in choosing an appropriate dose of the drug for a given patient. In people with slow metabolism, a lower dose of the drug is recommended due to the risk of adverse reactions.

For example, the recommendations of the Clinical Pharmacogenetics Implementation Consortium (CPIC; information is available on the Consortium website) indicate that three-ring antidepressants (TLPDs) should not be used in people with CYP2D6 or CYP2C19 genotypes with ultra-fast or slow metabolism, and a dose higher than $20 \mathrm{mg}$ per should not be used in patients treated with citalopram with a genotype with slow metabolism of the drug (Revised Recommendations for Celexa, [citalopram hydrobromide] related to a potential risk of abnormal heart rhythms with high doses [FDA Drug Safety Communication]. US Food and Drug Administration website, https://www.fda.gov/Drugs/DrugSafety/ucm297391.htm. Published March 28, 2012., n.d.; www.fda.gov/drugs/scienceresearch/researchareas/pharmacogenetics/, n.d.). Recommendations on the use of results of pharmacogenetic tests of cytochrome 4500 genes (so-called genetic passport) in the dosage of SSRI (selective serotonin reuptake inhibitors) are summarised in the article from 2015 (Hicks et al., 2015).

Information on the drug pharmacogenetics is contained in leaflets of many antidepressants (SSRI, TLPD) and antipsychotics (e.g. aripiprazole, clozapine, haloperidol, risperidone). Although this knowledge exists, physicians are often not able to use it, not least due to low availability and high costs of the test (Altar et al., 2015). Under the research activity, molecular tests in this field are performed by the Department of Experimental and Clinical Pharmacology at the Pomeranian Medical University in Szczecin.

A number of studies have shown that rare variants of the HLA - B*15.02 and HLA*31:01 genes are associated with the risk of serious adverse reactions in patients treated with carbamazepine and oxcarbazepine. According to the recommendations of the Clinical Pharmacogenetics Implentation Consortium, these drugs should not be used in patients with the HLA gene variants mentioned above. In many Asian countries, such as Taiwan, Thailand and Hong Kong, HLA tests are performed prior to taking carbamazepine to avoid serious side effects, such as Stevens-Johnson syndrome (Dean, 2012).

Experts emphasise that the tests are clinically useful in people who have experienced adverse reactions and in people who have not seen any improvement in their mental state after pharmacotherapy. Some clinical centres around the world perform pharmacogenetic tests prior to pharmacological treatment, although there is no clear position on this issue. Pharmacogenetic tests may be particularly useful in the selection of antidepressants (Nassan et al., 2016).
In the coming years, we expect to obtain the results of the current research on antipsychotic and normotymic drugs. The analysis of the results of this research may help us determine the optimal time to perform the test and indicate in which patients pharmacogenetic tests should be performed.

\section{Conclusions}

Due to the growing awareness of the importance of genetics and the availability of molecular testing, it is necessary to expand the medical services under psychiatric care. Disorders of complex etiology shaped by environmental factors and a number of genetic factors, including mental disorders, go beyond the standard clinical genetics advice.

The diagnosis of mental disorders has negative social implications, leading to stigmatisation and preserving the taboo. As a result, patients and their families find it difficult to cope with the burden. Better understanding of the disease aetiology as well as the sense of control and coping with the problem can bring measurable benefits to the quality of life of affected people. We have the grounds to see the psychiatric genetic counselling as an important and valuable means to improve cooperation with the doctor and comfort of patients and their families.

However, in order to train the specialists to conduct such consultations and to ensure their availability, further research with organisational, legal and financial efforts is required. A more personalised approach from the psychiatric care team and patient's willingness to cooperate can bring measurable benefits in the course of the disease.

Effective and safe use of the drug, including in particular the reduction of the risk of adverse reactions, is extremely important. Pharmacogenetic tests can facilitate individual therapeutic decisions, as they serve as an additional tool for the doctor which can be useful in clinical practice. Tests of the CYP2C19 and CYP2D6 genes associated with the metabolism of drugs may be clinically useful in patients who have experienced adverse reactions or patients with no improvement of mental condition. Currently, the use of HLA-A and HLA-B tests is recommended prior to carbamazepine therapy due to the risk of serious adverse reactions, in particular in some ethnic groups.

Specialist psychiatric genetic counselling along with referral to genetic tests in accordance with modern evidence of their usefulness gives high hopes for the rational use of technological achievements for the benefit of patients. The lack of use of genetic tests in psychiatric diagnoses can be seen as a limitation in counselling. However, this is because the complex multigenic nature of the aetiology of mental disorders is not taken into account. 


\section{Wstęp i cel pracy}

Współczesne społeczeństwo ma ułatwiony dostęp do informacji o postępach biotechnologii i nauk medycznych oraz coraz większą świadomość roli genów w zdrowiu i chorobach człowieka. Od stuleci obserwowano rodzinne występowanie zaburzeń psychicznych, i takie przesłanki epidemiologiczne wraz z rozwojem genetyki dały początek dzisiejszej nauce o złożonym i wielogenowym podłożu etiopatogenetycznym tych schorzeń. Obecny rozwój usług genetycznych direct-to-consumer może prowadzić do wzrostu zapotrzebowania na fachową indywidualną interpretację wyników przez lekarza (Austin, 2013). Pozostawienie pacjenta z wynikiem, który może nieść informacje wzbudzające silne poczucie niepokoju, bez adekwatnej interpretacji, jest niewłaściwe z punktu widzenia etyki lekarskiej.

Badania genetyczne $w$ psychiatrii rozwinęły się w ostatnich dziesięcioleciach XX wieku i początkowo czerpały z narzędzi i doświadczeń genetyki klinicznej chorób monogenowych (Austin, 2013). Dopiero rozwój technologiczny i pojęcie uwarunkowań wielogenowych, metod GWAS i PRS przyniosły silne naukowe dowody, że większość zaburzeń psychicznych należy do schorzeń o bardziej złożonym mechanizmie rozwoju (Cardno and Owen, 2014).

W Polsce ośrodki badawcze w Poznaniu, Szczecinie, Wrocławiu, Warszawie i innych miastach akademickich prowadziły badania genetyczne w psychiatrii. Udzielano także konsultacji dla zainteresowanych pacjentów w formie niesformalizowanej. W 1999 roku w Katedrze Psychiatrii Akademii Medycznej w Poznaniu utworzono Pracownię, a następnie Zakład Genetyki w Psychiatrii, pod kierunkiem prof. dr hab. Joanny Twarowskiej-Hauser. Jesienią 2019 wyodrębniono w nim Pracownię Poradnictwa Genetycznego w Psychiatrii. Inspiracją ku temu były, oprócz doświadczeń własnych, działalność od 2012 roku Adapt Clinic w Vancouver w Kanadzie oraz sieć badawcza rozwijana w ramach grantu europejskiego EnGagE (Enhancing Psychiatric Genetic Counselling, Testing, and Training in Europe).

W niniejszej pracy przedstawimy założenia poradnictwa genetycznego w psychiatrii, jego znaczenie dla pacjentów oraz zastosowanie użyteczne dla klinicystów na obecnym etapie wiedzy.

\section{Przegląd piśmiennictwa}

\section{Jak definiować poradnictwo genetyczne w psychiatrii?}

Poradnictwo genetyczne współcześnie jest definiowane jako proces, który pomaga ludziom zrozumieć medyczne, psychologiczne i rodzinne następstwa genetycznego obciążenia jakimś schorzeniem i zaadaptować się do nich (Resta i wsp., 2006). Harper podkreśla znaczenie informowania o konsekwencjach związanych z chorobą, o sposobie dziedziczenia oraz o metodach, które mogą pomóc w powstrzymaniu, uniknięciu lub zminimalizowaniu objawów (za: Hauser, 2011). Trzeba jednak mieć na uwadze także aspekt humanistyczny i holistyczny, tj. psychospołeczne potrzeby pacjenta oraz poszanowanie jego praw, w tym prawa do autonomii i podejmowania świadomych decyzji. Mając w pamięci historyczne działania wykorzystujące genetyczną wiedzę o zaburzeniach psychicznych (Propping, 2005), należy wymagać wysokich standardów etycznych i kompetencji w zakresie udzielania porad $i$ kierowania na testy genetyczne $w$ tej dziedzinie.

W niektórych państwach, takich jak Stany Zjednoczone, Kanada, Francja, Norwegia, Portugalia, Hiszpania, Rumunia i Wielka Brytania, wyodrębniono zawód doradcy genetycznego. Podobnie jest w Australii, Afryce Południowej, Izraelu i na Filipinach. W krajach tych dostępne są szkolenia uprawniające do wykonywania takiego zawodu (Moldovan i wsp., 2019). W Polsce porad genetycznych udzielają lekarze o specjalizacji z genetyki klinicznej. Tylko niektóre badania molekularne są finansowane przez Narodowy Fundusz Zdrowia. Natomiast oferta laboratoriów komercyjnych wykonujących badania „na życzenie" i na koszt klienta jest na świecie bardzo szeroka i dostępna także dla zainteresowanych z Polski.

Specjaliści genetyki klinicznej mają świadomość, że nie dysponujemy obecnie testami molekularnymi do celów diagnozowania lub prognozowania zachorowania na zaburzenia psychiczne (Austin, 2013). Zniechęca to do podejmowania dialogu z pacjentami szukającymi odpowiedzi na pytania o obciążenia rodzinne zaburzeniami psychicznymi. W konsekwencji udzielanie konsultacji genetycznej tej grupie jest znacznie ograniczone (Appelbaum and Benston, 2017; Lyus, 2007; Monaco i wsp., 2010). Natomiast lekarze psychiatrzy często nie czują się dość pewnie w interpretacji wyników badań molekularnych. Nie istnieje możliwość odbycia podyplomowego szkolenia z zakresu genetyki psychiatrycznej w Polsce. Specjalistyczne szkolenia prowadzi cyklicznie Uniwersytet w Bournemouth, Wielka Brytania (https://research. bournemouth.ac.uk/wp-content/uploads/2016/10/PG4GC3.pdf, 2020). W roku $2019 \mathrm{w}$ ramach grantu europejskiego CA17130 Enhancing Psychiatric Genetic Counselling, Testing, and Training in Europe odbyły się Paryżu warsztaty o tej samej tematyce (https://www.cost.eu/ cost-action/enhancing-psychiatric-genetic-counselling-testing-and-training-in-europe/\#tabs|Name:overview, 2020). Z Polski wzięli w nich udział lekarze oraz diagności laboratoryjni pracujący w dziedzinie genetyki psychiatrycznej.

Konsultacje z przeszkolonymi tą drogą badaczami Poznańskiego Uniwersytetu Medycznego mogą się odbywać na życzenie pacjenta lub rodziny z obciążeniami psychiatrycznymi bez skierowania, czyli na tych samych zasadach, co wizyty u psychiatry. Skierowania na 
ewentualne badania molekularne wydawane są przez specjalistów genetyki klinicznej w sytuacji, gdy psychiatra skieruje do takiej poradni. Jest to uzasadnione w wybranych przypadkach, głównie zaburzeń o charakterze niepełnosprawności intelektualnej lub autyzmu, o ile podejrzewana jest obecność specyficznej mutacji. Z drugiej strony w przypadku niektórych mutacji związanych z występowaniem zespołów wad wrodzonych (np. wady serca i podniebienia) istnieje podwyższone prawdopodobieństwo manifestacji objawów psychopatologicznych. Przykładem może być zespół delecji 22q11.2 (zespół di George’a), w którym ryzyko zachorowania na schizofrenię ponad dwudziestokrotnie przekracza ryzyko populacyjne (Bassett i wsp., 2017; Fung i wsp., 2010). W tym zespole genetycznym zwiększone jest także ryzyko występowania zespołu lęku uogólnionego (Fung i wsp., 2010). Jednak większość pacjentów obciążonych delecją 22q11.2 nie choruje na schizofrenię. Natomiast wśród osób z ustaloną diagnozą schizofrenii delecję 22q11.2 stwierdza się u 0,5-1\% pacjentów (Bassett i wsp., 2010).

W tego rodzaju sytuacjach diagnostyka molekularna może zostać przeprowadzona już w okresie prenatalnym i wczesnodziecięcym. Konieczne jest jednak podkreślenie, że stwierdzenie wspomnianej mutacji nie może służyć diagnozowaniu schizofrenii i stygmatyzacji badanych. Poszukiwania mutacji CNV (copy number variants) w zaburzeniach psychicznych dostarczają kolejnych dowodów na ich wielogenowe podłoże (Bassett i wsp., 2017).

W przypadku ujawnienia silnej genetycznej predyspozycji do choroby takiej jak schizofrenia, czyli potencjalnie rozpoczynającej się z opóźnieniem w stosunku do przeprowadzonego badania molekularnego, nabiera znaczenia możliwość i swoistość profilaktyki. W przypadku wysokiego ryzyka psychozy opracowano strategie farmakologiczne i psychoterapeutyczne mające na celu obniżenie wskaźnika przejścia w pełnoobjawową chorobę (Fusar-Poli i wsp., 2016; Schmidt i wsp., 2015). Jednak obecnie nie ma dowodów na wyższość którejś z nich w uzyskiwaniu poprawy wyników klinicznych (Nelson i wsp., 2020). Poważne wątpliwości etyczne budzi wykonywanie testów genetycznych, zwłaszcza u dzieci, w kierunku chorób, co do których nie istnieje postępowanie prewencyjne, przykładowo w chorobie Huntingtona.

Sama konsultacja genetyczna w psychiatrii obejmuje trzy zasadnicze elementy: interpretację rodzinnych obciążeń medycznych, edukację oraz wsparcie umożliwiające podejmowanie świadomych decyzji przez pacjenta (Resta i wsp., 2006). Sporządzenie drzewa genealogicznego uwzględniającego zaburzenia psychiczne natrafia niejednokrotnie na trudności wynikające $\mathrm{z}$ braku dokumentacji medycznej lub tabu, jakim w rodzinach otaczane są diagnozy psychiatryczne. Następnie szacowane jest ryzyko wystąpienia zaburzeń na podstawie badań empirycznych (Hill and Sahhar, 2006) i obciążeń rodzinnych. Niejednokrotnie oczekiwania co do precyzji takich przewidywań są wygórowane - ze względu na pomijanie znaczenia czynników środowiskowych. W przypadku zaburzeń psychicznych precyzyjne wyliczenie indywidualnego ryzyka zachorowania nie jest możliwe (Hauser, 2011, s. 20).

Drugim elementem jest edukacja na temat odziedziczalności, wykonywania badań molekularnych, zapobiegania zaburzeniom psychicznym oraz rozróżnienia między wynikami badawczymi i diagnostycznymi. Wypełnienie tej luki jest niezbędne, by pacjent mógł uwolnić się z nieuzasadnionego pesymizmu i determinizmu związanego z wynikami genetycznymi lub z równie nieuzasadnionego optymizmu co do możliwości medycznych (Friesen i wsp., 2016; Moldovan i wsp., 2019). Warto przy tym wziąć pod uwagę, że to pacjent ocenia znaczenie udzielonej mu informacji. Jeśli określimy ryzyko zachorowania jako 50-proc., dla jednych oznaczać to będzie ryzyko zbyt duże do podźwignięcia, a dla innych szansę na zdrowie w połowie przypadków.

Kluczowe w takich sytuacjach okazują się umiejętności empatycznego oddziaływania przez lekarza. Konieczna staje się pomoc pacjentowi w zaadaptowaniu się do sytuacji zaistniałych obciążeń genetycznych, ich tolerowania przez redukcję lęku, poczucia bezradności i braku kontroli. Pozyskana wiedza i zrównoważone emocje umożliwiają pacjentowi dokonywanie świadomych wyborów uwzględniających jego mocne i słabe strony. $\mathrm{W}$ tym elemencie poradnictwo genetyczne $\mathrm{w}$ psychiatrii najbardziej zbliża się do wybranych aspektów psychoterapii i może okazać się trudne do zrealizowania przez specjalistę genetyka czy biotechnologa. Dlatego uzasadnione jest zaplanowanie konsultacji genetycznej w psychiatrii na co najmniej dwa spotkania, co umożliwia wsparcie $\mathrm{w}$ procesie adaptacji i ułatwia zaangażowanie interdyscyplinarnego zespołu.

W tym kontekście komercyjna dostępność testów genetycznych określanych jako "diagnostyczne" w zakresie zaburzeń psychicznych należy ocenić krytycznie z wielu względów. Po pierwsze, stawianie diagnozy psychiatrycznej w oparciu o sam wynik badania obecności lub braku wybranych polimorfizmów genetycznych jest błędem. Lista polimorfizmów mających wpływ na zachorowanie nie jest obecnie kompletna. Podstawą diagnozy zgodnie z kryteriami klasyfikacji międzynarodowych ICD-10 oraz DSM-5 jest wyłącznie występowanie objawów klinicznych. Przesyłanie zarówno materiału do badania molekularnego (często za granicę), jak i samego wyniku (często w drodze elektronicznej o nieokreślonych zabezpieczeniach) stwarza sytuacje związane $\mathrm{z}$ wielorakim ryzykiem (niewłaściwe warunki przechowywania materiału, niemożność zweryfikowania źródła próbki, brak kontroli nad poufnością danych, możliwość gromadzenia danych genetycznych przez podmioty o charakterze komercyjnym $i$ działające poza polskim systemem prawnym i inne). Przekazanie wyniku bez jego rzetelnej interpretacji może być źródłem traumy i mieć niekorzystny wpływ na życiowe decyzje badanego. 
Tsuang i wsp. wskazują na sześć etapów konsultacji genetycznej w psychiatrii (Tsuang i wsp., 2001), które są zbieżne z wcześniej opisanymi elementami:

- określenie diagnozy (jej postawienie lub weryfikacja, zależnie od etapu, na którym dochodzi do konsultacji);

- nakreślenie drzewa genealogicznego zawierającego niezbędne dane medyczne;

- ocena modelu dziedziczenia i ryzyka zachorowania (uwzględniając częściowe nakładanie się polimorfizmów predysponujących do różnych zaburzeń i różnorodność fenotypową);

- ocena osoby konsultowanej pod względem emocjonalnym i intelektualnym i dostosowanie przekazu do jej potrzeb;

- wskazanie mocnych i słabych stron wynikających z przedstawianych informacji i pomoc w ich przyjęciu w zgodzie z systemem wartości, oczekiwaniami i planami pacjenta;

- asystowanie w wytyczeniu dalszego postępowania, w tym decyzja o testach molekularnych i zaleceniach klinicznych;

- podsumowanie, które może obejmować uzupełnienie danych po okresie dalszej obserwacji pacjenta, i pisemne sformułowanie wniosków pokonsultacyjnych.

\section{Co zyskuje pacjent? Potrzeby i efekty poradnictwa}

Pacjenci zgłaszający potrzebę konsultacji genetycznej w większości należą do następujących grup:

- osoby z diagnozą zaburzenia psychicznego planujące potomstwo lub spodziewające się dziecka,

- rodzice lub dziadkowie dzieci z podwyższonym ryzykiem wystąpienia zaburzeń psychicznych,

- rodzice dzieci z diagnozą zaburzeń psychicznych,

- dotychczas zdrowe rodzeństwo lub dzieci osób z diagnozą zaburzenia psychicznego,

- inni krewni z rodzinnym obciążeniem zaburzeniami psychicznymi,

- osoby z diagnozą zaburzenia psychicznego pogłębiające wiedzę o swoim stanie zdrowia,

- osoby z niepokojącymi objawami niesklasyfikowanymi dotychczas, poszukujący wyjaśnienia dolegliwości (Peay and Austin, 2011).

Motywacja i oczekiwania konsultowanych osób mogą się różnić, jednak opisany wyżej ogólny schemat porady jest wspólny. Osoby zgłaszające się po poradę przeżywają niepokój o siebie i bliskich, doświadczają poczucia winy lub bezsilności.

Na podstawie badań w państwach, w których psychiatryczne poradnictwo genetyczne zostało włączone do oferty usług medycznych, stwierdzono jego korzystne efekty. Po konsultacji genetycznej należy oczekiwać, że wiedza pacjenta o ryzyku będzie zbliżona do danych medycznych, a nie czerpana z niezweryfikowanych źródeł. Pacjent uzyska informacje o modyfikowalnych czynnikach ryzyka i czynnikach ochronnych (redukcji ryzyka). Podniesiona zostanie wiarygodność diagnozy i trafność postępowania. Urealnieniu ulegną oczekiwania co do testów genetycznych i terapii genowej (Peay and Austin, 2011).

Grupa badaczy z Adapt Clinic (Vancouver) w okresie luty 2012 - styczeń 2013 gromadziła dane dotyczące poczucia możności (ang. empowerment) oraz poczucia własnej skuteczności w radzeniu sobie z chorobą, przy pomocy dedykowanych skal GCOS (Genetic Counseling Outcome Scale) i IMSES (Illness Management Self Efficacy Scale), (Inglis i wsp., 2015). Poczucie możności według definicji autorów opisuje zestaw przekonań osób z rodziny dotkniętej obciążeniami genetycznymi, że mają one w pewnym stopniu kontrolę nad sytuacją i nadzieję na przyszłość. Skalę IMSES wypełniali tylko pacjenci mający w wywiadzie diagnozę zaburzeń psychicznych. Natomiast skala GCOS mogła być wypełniana również przez osoby zdrowe z obciążeniem rodzinnym. W zakresie obydwu skal stwierdzono istotny statystycznie wzrost parametrów po udzieleniu psychiatrycznej konsultacji genetycznej. To natomiast ma związek ze zmniejszeniem poczucia stygmatyzacji, beznadziejności i bezradności oraz z poprawą jakości życia i korzystania ze wsparcia.

Obserwowano także poprawę wiedzy o etiologii choroby i zmniejszenie obwiniania siebie za chorobę. Lepsze rozumienie etiologii choroby może przyczynić się do poprawy współpracy w leczeniu farmakologicznym (Costain i wsp., 2014b). Natomiast u członków rodzin pacjentów stwierdzono zmniejszenie obaw związanych z nawrotami choroby (Costain i wsp., 2014a).

\section{Przydatność farmakogenetyki w praktyce psychiatry}

Celem badań farmakogenetycznych jest określenie genetycznych markerów dotyczących klinicznego efektu działania leków i prawdopodobieństwa występowania objawów ubocznych. Badania te obejmują analizy pojedynczych polimorfizmów genów kandydujących, które związane są z farmakokinetycznym i farmakodynamicznym mechanizmem działania leków oraz badania asocjacyjne całego genomu (GWAS, genome wide association studies) (Foley i wsp., 2017; Rybakowski, 2019; Rybakowski, 2014; Serretti, 2017; van Westrhenen i wsp., 2020; Yoshida and Müller, 2019).

Międzynarodowe Towarzystwo Genetyki w Psychiatrii, ISPG (The International Society of Psychiatric Genetics) od 2013 roku przedstawia rekomendacje dotyczące stosowania testów farmakogenetycznych w praktyce klinicznej. Obecna rekomendacja ISPG została przyjęta w listopadzie 2019. Zdaniem ekspertów Międzynarodowego Towarzystwa Genetyki w Psychiatrii dotychczasowe wyniki badań farmakogenetycznych mają istotne znaczenie naukowe, wskazano na wiele markerów genetycznych związanych z efektem terapeutycznym leków stosowanych w psychiatrii. Większość opisanych markerów nie spełnia obecnie kryterium testu klinicznego, 
konieczne są zatem dalsze badania potwierdzające ich znaczenie w praktyce klinicznej (Hirschtritt i wsp., 2016; Nurnberger i wsp., 2018).

Eksperci ISPG wskazują, że istotne znaczenie w praktyce klinicznej mogą mieć warianty genów CYP2D6 i CYP2C19, związane z metabolizmem leków stosowanych w psychiatrii, w szczególności leków przeciwdepresyjnych i przeciwpsychotycznych. Warianty genów CYP2D6 i CYP2C19, wpływając na metabolizm leków, związane są z ryzykiem występowania objawów niepożądanych lub brakiem skuteczności terapeutycznej leków. Przeprowadzenie testu genetycznego może okazać się pomocne w dobraniu odpowiedniej dawki leku dla danego pacjenta. U osób charakteryzujących się wolnym metabolizmem, ze względu na ryzyko występowania objawów niepożądanych, zalecana jest niższa dawka leku.

W rekomendacjach Clinical Pharmacogenetics Implementation Consortium (CPIC; informacje są dostępne na stronie konsorcjum) wskazuje się na przykład, że u osób z genotypem CYP2D6 lub CYP2C19, związanym z ultra szybkim lub wolnym metabolizmem nie należy stosować trójpierścieniowych leków przeciwdepresyjnych (TLPD), a u pacjentów leczonych citalopramem z genotypem związanym z wolnym metabolizmem leku nie należy stosować dawki leku wyższej niż 20 mg na dzień (Revised Recommendations for Celexa [citalopram hydrobromide] related to a potential risk of abnormal heart rhythms with high doses [FDA Drug Safety Communication]. US Food and Drug Administration website, https://www.fda. gov/Drugs/DrugSafety/ucm297391.htm. Published March 28, 2012., n.d.; www.fda.gov/drugs/scienceresearch/researchareas/pharmacogenetics/, n.d.). Rekomendacje dotyczące wykorzystania wyników badań farmakogenetycznych genów cytochromu p450 (tzw. paszportu genetycznego) w dawkowaniu SSRI (selektywne inhibitory wychwytu zwrotnego serotoniny) podsumowano w artykule z 2015 roku (Hicks i wsp., 2015).

Informacje dotyczące farmakogenetyki leku zawarte są w ulotkach wielu leków przeciwdepresyjnych (SSRI, TLPD) i leków przeciwpsychotycznych (np. aripiprazol, klozapina, haloperidol, risperidon). Pomimo iż wiedza ta istnieje i można z niej czerpać, lekarze często nie mają praktycznej możliwości korzystania z niej, choćby ze względu na dostępność i koszty związane z wykonaniem testu (Altar i wsp., 2015). W ramach działalności badawczej badania molekularne w tym zakresie wykonuje Zakład Farmakologii Doświadczalnej i Klinicznej Pomorskiego Uniwersytetu Medycznego w Szczecinie.

W wielu badaniach wskazano, że rzadko występujące warianty genów HLA - B*15.02 i $H L A^{*} 31$ :01 związane są z ryzykiem występowania poważnych objawów niepożądanych u pacjentów leczonych karbamazepiną i okskarbazepiną. Według zaleceń Clinical Pharmacogenetics Implentation Consortium nie należy stosować tych leków u pacjentów ze wskazanymi wariantami genów HLA. W wielu krajach azjatyckich, takich jak Tajwan,
Tajlandia, Hong Kong, testy HLA wykonuje się u pacjentów przed podjęciem farmakoterapii karbamazepiną w celu uniknięcia poważnych objawów ubocznych, takich jak Zespół Stevensa-Johnsona (Dean, 2012).

Eksperci podkreślają, że testy są przydatne klinicznie u osób, u których wystąpiły objawy niepożądane, oraz u osób, u których nie obserwowano poprawy stanu psychicznego po zastosowanej farmakoterapii. Część ośrodków klinicznych na świecie wykonuje testy farmakogenetyczne przed podjęciem leczenia farmakologicznego, choć nie ma co do tego jednoznacznego stanowiska. Testy farmakogenetyczne mogą być szczególnie przydatne w wyborze leków przeciwdepresyjnych (Nassan i wsp., 2016).

W najbliższych latach oczekujemy wyników prowadzonych obecnie badań dotyczących leków przeciwpsychotycznych i normotymicznych. Analiza tych prac może przyczynić się do określenia optymalnego czasu, kiedy należy wykonać test u pacjenta, a także pozwoli na wskazanie, u których pacjentów należy wykonywać testy farmakogenetyczne.

\section{Wnioski}

Rosnąca świadomość znaczenia genetyki i dostępność badań molekularnych wymagają poszerzenia oferowanych usług medycznych w opiece psychiatrycznej. Zaburzenia o złożonej etiologii, uwarunkowane czynnikami środowiskowymi i licznymi czynnikami genetycznymi, do których należą zaburzenia psychiczne, wykraczają poza rutynowe obszary porad w ramach genetyki klinicznej.

Społeczne implikacje diagnozy zaburzeń psychicznych i związana z nią stygmatyzacja i tabu niekorzystnie wpływają na radzenie sobie $\mathrm{z}$ takim obciążeniem przez rodziny i samych pacjentów. Dlatego poprawa w zakresie rozumienia etiologii choroby, poczucia kontroli i radzenia sobie może przynieść wymierne korzyści dla jakości życia dotkniętych chorobą osób. Mamy powody, by uważać poradnictwo genetyczne w psychiatrii za ważny i wartościowy środek służący poprawie współpracy z lekarzem oraz komfortu pacjenta i rodziny.

Jednak szkolenie i dostępność do specjalistów prowadzących takie konsultacje wymaga dalszych wysiłków badawczych, organizacyjnych, prawnych i finansowych. Bardziej spersonalizowane podejście ze strony zespołu opieki psychiatrycznej i poprawa współpracy ze strony pacjenta mogą dać wymierne korzyści w przebiegu choroby.

Skuteczne i bezpieczne stosowanie leku, w szczególności zmniejszenie ryzyka wystąpienia objawów niepożądanych, jest niezwykle istotne. Testy farmakogenetyczne mogą ułatwiać indywidualne decyzje terapeutyczne, są bowiem dodatkowym narzędziem dla lekarza, które może być przydatne w praktyce klinicznej. Testy genów CYP2C19 i CYP2D6 związanych z metabolizmem leków mogą być przydatne klinicznie u pacjentów, u których wystąpiły objawy niepożądane lub u których nie 
uzyskano poprawy stanu psychicznego. W chwili obecnej zaleca się stosowanie testu HLA-A i HLA-B przed terapią karbamazepiną, ze względu na ryzyko wystąpienia poważnych objawów niepożądanych, w szczególności w niektórych grupach etnicznych.

Natomiast specjalistyczne poradnictwo genetyczne w psychiatrii oraz kierowanie na testy genetyczne

Conflict of interest and financial support non declared. / Nie zgłoszono konfliktu interesów oraz dofinansowania.

The work described in this article has been carried out in accordance with The Code of Ethics of the World Medical Association (Declaration of Helsinki) for experiments involving humans, EU Directive 2010/63/EU for animal experiments, and Uniform Requirements for manuscripts submitted to biomedical journals. / Treści przedstawione w artykule są zgodne z zasadami Deklaracji Helsińskiej, dyrektywami EU oraz ujednoliconymi wymaganiami dla czasopism biomedycznych.

Authors' contributions / Wkład autorów: Authors had equal contribution to the manuscript preparation. / Wkład autorów w przygotowanie pracy był równy.

\section{References / Piśmiennictwo}

1. Altar, C.A., Carhart, J., Allen, J.D., Hall-Flavin, D., Winner, J., Dechairo, B., 2015. Clinical Utility of Combinatorial Pharmacogenomics-Guided Antidepressant Therapy: Evidence from Three Clinical Studies. Mol. Neuropsychiatry 1, 145-155. https://doi.org/10.1159/000430915

2. Appelbaum, P.S., Benston, S., 2017. Anticipating the Ethical Challenges of Psychiatric Genetic Testing. Curr. Psychiatry Rep. 19, 39. https://doi.org/10.1007/s11920-017-0790-x

3. Austin, J., 2013. Genetic Testing for Psychiatric Disorders: Its Current Role in Clinical Psychiatric Practice 30.

4. Bassett, A.S., Costain, G., Alan Fung, W.L., Russell, K.J., Pierce, L., Kapadia, R., Carter, R.F., Chow, E.W.C., Forsythe, P.J., 2010. Clinically detectable copy number variations in a Canadian catchment population of schizophrenia. J. Psychiatr. Res. 44, 1005-1009. https://doi.org/10.1016/j.jpsychires.2010.06.013

5. Bassett, A.S., Lowther, C., Merico, D., Costain, G., Chow, E.W.C., van Amelsvoort, T., McDonald-McGinn, D., Gur, R.E., Swillen, A., Van den Bree, M., Murphy, K., Gothelf, D., Bearden, C.E., Eliez, S., Kates, W., Philip, N., Sashi, V., Campbell, L., Vorstman, J., Cubells, J., Repetto, G.M., Simon, T., Boot, E., Heung, T., Evers, R., Vingerhoets, C., van Duin, E., Zackai, E., Vergaelen, E., Devriendt, K., Vermeesch, J.R., Owen, M., Murphy, C., Michaelovosky, E., Kushan, L., Schneider, M., Fremont, W., Busa, T., Hooper, S., McCabe, K., Duijff, S., Isaev, K., Pellecchia, G., Wei, J., Gazzellone, M.J., Scherer, S.W., Emanuel, B.S., Guo, T., Morrow, B.E., Marshall, C.R., International 22q11.2DS Brain and Behavior Consortium, 2017. Rare Genome-Wide Copy Number Variation and Expression of Schizophrenia in 22q11.2 Deletion Syndrome. Am. J. Psychiatry 174, 1054-1063. https:// doi.org/10.1176/appi.ajp.2017.16121417.

6. Cardno, A.G., Owen, M.J., 2014. Genetic Relationships Between Schizophrenia, Bipolar Disorder, and Schizoaffective zgodnie ze współczesnymi dowodami ich przydatności daje duże nadzieje na racjonalne wykorzystanie zdobyczy technologicznych dla dobra pacjentów. Brak testów genetycznych służących stawianiu diagnoz psychiatrycznych można traktować jako ograniczenie poradnictwa. Jednak wynika to z niezrozumienia złożonej, wielogenowej etiologii tych chorób.

Disorder. Schizophr. Bull. 40, 504-515. https://doi. org/10.1093/schbul/sbu016

7. Costain, G., Esplen, M.J., Toner, B., Hodgkinson, K.A., Bassett, A.S., 2014a. Evaluating Genetic Counseling for Family Members of Individuals With Schizophrenia in the Molecular Age. Schizophr. Bull. 40, 88-99. https://doi.org/10.1093/ schbul/sbs124

8. Costain, G., Esplen, M.J., Toner, B., Scherer, S.W., Meschino, W.S., Hodgkinson, K.A., Bassett, A.S., 2014b. Evaluating Genetic Counseling for Individuals With Schizophrenia in the Molecular Age. Schizophr. Bull. 40, 78-87. https://doi. org/10.1093/schbul/sbs138

9. Dean, L., 2012. Carbamazepine Therapy and HLA Genotype, in: Pratt, V.M., McLeod, H.L., Rubinstein, W.S., Scott, S.A., Dean, L.C., Kattman, B.L., Malheiro, A.J. (Eds.), Medical Genetics Summaries. National Center for Biotechnology Information (US), Bethesda (MD).

10. Foley, C., Corvin, A., Nakagome, S., 2017. Genetics of Schizophrenia: Ready to Translate? Curr. Psychiatry Rep. 19, 61. https://doi.org/10.1007/s11920-017-0807-5

11. Friesen, P., Lawrence, R.E., Brucato, G., Girgis, R.R., Dixon, L., 2016. Hopes and Expectations Regarding Genetic Testing for Schizophrenia Among Young Adults at Clinical High-Risk for Psychosis: J. Psychiatr. Pract. 22, 442-449. https://doi. org/10.1097/PRA.0000000000000188

12. Fung, W.L.A., McEvilly, R., Fong, J., Silversides, C., Chow, E., Bassett, A., 2010. Elevated Prevalence of Generalized Anxiety Disorder in Adults With 22q11.2 Deletion Syndrome. Am. J. Psychiatry 167, 998-998. https://doi.org/10.1176/appi. ajp.2010.09101463

13. Fusar-Poli, P., Cappucciati, M., Borgwardt, S., Woods, S.W., Addington, J., Nelson, B., Nieman, D.H., Stahl, D.R., Rutigliano, G., Riecher-Rössler, A., Simon, A.E., Mizuno, M., Lee, T.Y., Kwon, J.S., Lam, M.M.L., Perez, J., Keri, S., Amminger, P., Metzler, S., Kawohl, W., Rössler, W., Lee, J., Labad, J., Ziermans, T., An, S.K., Liu, C.-C., Woodberry, K.A., Braham, A., Corcoran, C., McGorry, P., Yung, A.R., McGuire, P.K., 2016. Heterogeneity of Psychosis Risk Within Individuals at Clinical High Risk: A Meta-analytical Stratification. JAMA Psychiatry 73, 113. https://doi.org/10.1001/jamapsychiatry.2015.2324

14. Hauser, J., 2011. Konsultacja genetyczna w psychiatrii - kontrowersje. Psychiatr. Po Dyplomie 8.

15. Hicks, J., Bishop, J., Sangkuhl, K., Müller, D., Ji, Y., Leckband, S., Leeder, J., Graham, R., Chiulli, D., LLerena, A., Skaar, T., Scott, S., Stingl, J., Klein, T., Caudle, K., Gaedigk, A., 2015. Clinical Pharmacogenetics Implementation Consortium (CPIC) Guideline for CYP2D6 and CYP2C19 Genotypes and Dosing of Selective Serotonin Reuptake Inhibitors. Clin. Pharmacol. Ther. 98, 127-134. https://doi.org/10.1002/cpt.147 
16. Hill, M.K., Sahhar, M., 2006. Genetic counselling for psychiatric disorders. Med. J. Aust. 185, 507-510.

17. Hirschtritt, M.E., Besterman, A.D., Ross, D.A., 2016. Psychiatric Pharmacogenomics: How Close Are We? Biol. Psychiatry 80, e63-e65. https://doi.org/10.1016/j.biopsych.2016.08.007

18. https://research.bournemouth.ac.uk/wp-content/uploads/ 2016/10/PG4GC3.pdf, 2020.

19. https://www.cost.eu/cost-action/enhancing-psychiatricgenetic-counselling-testing-and-training-in-europe/\#tabs|Name:overview, 2020.

20. Inglis, A., Koehn, D., McGillivray, B., Stewart, S.E., Austin, J., 2015. Evaluating a unique, specialist psychiatric genetic counseling clinic: uptake and impact: Evaluating a specialist psychiatric genetic counseling clinic. Clin. Genet. 87, 218-224. https://doi.org/10.1111/cge.12415

21. Lyus, V.L., 2007. The importance of genetic counseling for individuals with schizophrenia and their relatives: Potential clients' opinions and experiences. Am. J. Med. Genet. B Neuropsychiatr. Genet. 144B, 1014-1021. https://doi.org/10.1002/ ajmg.b.30536

22. Moldovan, R., McGhee, K.A., Coviello, D., Hamang, A., Inglis, A., Ingvoldstad Malmgren, C., Johansson-Soller, M., Laurino, M., Meiser, B., Murphy, L., Paneque, M., Papsuev, O., Pawlak, J., Rovira Moreno, E., Serra-Juhe, C., Shkedi-Rafid, S., Laing, N., Voelckel, M., Watson, M., Austin, J.C., 2019. Psychiatric genetic counseling: A mapping exercise. Am. J. Med. Genet. B Neuropsychiatr. Genet. 180, 523-532. https:// doi.org/10.1002/ajmg.b.32735.

23. Monaco, L.C., Conway, L., Valverde, K., Austin, J.C., 2010. Exploring Genetic Counselors\&rsquo; Perceptions of and Attitudes towards Schizophrenia. Public Health Genomics 13, 21-26. https://doi.org/10.1159/000210096.

24. Nassan, M., Nicholson, W.T., Elliott, M.A., Rohrer Vitek, C.R., Black, J.L., Frye, M.A., 2016. Pharmacokinetic Pharmacogenetic Prescribing Guidelines for Antidepressants: A Template for Psychiatric Precision Medicine. Mayo Clin. Proc. 91, 897-907. https://doi.org/10.1016/j.mayocp.2016.02.023

25. Nelson, B., Amminger, G.P., Thompson, A., Wood, S.J., Yung, A.R., McGorry, P.D., 2020. Commentary: Preventive Treatments for Psychosis: Umbrella Review (Just the Evidence). Front. Psychiatry 11, 488. https://doi.org/10.3389/ fpsyt.2020.00488

26. Nurnberger, J.I., Austin, J., Berrettini, W.H., Besterman, A.D., DeLisi, L.E., Grice, D.E., Kennedy, J.L., Moreno-De-Luca, D., Potash, J.B., Ross, D.A., Schulze, T.G., Zai, G., 2018. What Should a Psychiatrist Know About Genetics?: Review and Recommendations From the Residency Education Committee of the International Society of Psychiatric Genetics. J. Clin. Psychiatry 80. https://doi.org/10.4088/JCP.17nr12046

27. Peay, H., Austin, J., 2011. How to talk with families about genetics and psychiatric illness. W.W. Norton, New York; London.

28. Propping, P., 2005. The biography of psychiatric genetics: From early achievements to historical burden, from an anxious society to critical geneticists. Am. J. Med. Genet. B Neuropsychiatr. Genet. 136B, 2-7. https://doi.org/10.1002/ajmg.b.30188.

29. Resta, R., Biesecker, B.B., Bennett, R.L., Blum, S., Estabrooks Hahn, S., Strecker, M.N., Williams, J.L., 2006. A New Definition of Genetic Counseling: National Society of Genetic Counselors' Task Force Report. J. Genet. Couns. 15, 77-83. https://doi.org/10.1007/s10897-005-9014-3

30. Revised recommendations for Celexa (citalopram hydrobromide) related to a potential risk of abnormal heart rhythms with high doses [FDA Drug Safety Communication]. US Food and Drug Administration website. https://www.fda.gov/Drugs/ DrugSafety/ucm297391.htm. Published March 28, 2012., n.d.

31. Rybakowski, J.K., 2014. Response to Lithium in Bipolar Disorder: Clinical and Genetic Findings. ACS Chem. Neurosci. 5, 413-421. https://doi.org/10.1021/cn5000277

32. Rybakowski J.K., 2019. Lit. Niezwykły lek w psychiatrii., 1st ed. Termedia, Poznań.

33. Schmidt, S.J., Schultze-Lutter, F., Schimmelmann, B.G., Maric, N.P., Salokangas, R.K.R., Riecher-Rössler, A., van der Gaag, M., Meneghelli, A., Nordentoft, M., Marshall, M., Morrison, A., Raballo, A., Klosterkötter, J., Ruhrmann, S., 2015. EPA guidance on the early intervention in clinical high risk states of psychoses. Eur. Psychiatry 30, 388-404. https:// doi.org/10.1016/j.eurpsy.2015.01.013

34. Serretti, A., 2017. Genetics and pharmacogenetics of mood disorders. Psychiatr. Pol. 51, 197-203. https://doi.org/ 10.12740/PP/68914

35. Tsuang, D.W., Faraone, S.V., Tsuang, M.T., 2001. Genetic counseling for psychiatric disorders. Curr. Psychiatry Rep. 3, 138-143. https://doi.org/10.1007/s11920-001-0011-4

36. US Food and Drug Administration website, www.fda.gov/drugs/ scienceresearch/researchareas/pharmacogenetics/, n.d.

37. van Westrhenen, R., Aitchison, K.J., Ingelman-Sundberg, M., Jukić, M.M., 2020. Pharmacogenomics of Antidepressant and Antipsychotic Treatment: How Far Have We Got and Where Are We Going? Front. Psychiatry 11, 94. https://doi.org/ 10.3389/fpsyt.2020.00094

38. Yoshida, K., Müller, D.J., 2019. Pharmacogenetics of Antipsychotic Drug Treatment: Update and Clinical Implications. Mol. Neuropsychiatry 5, 1-26. https://doi.org/ $10.1159 / 000492332$ 
